\title{
Sweet bread chemical properties optimalization based on baking
}

\section{temperature and duration}

\section{Devi Dwi Siskawardani ${ }^{1 *}$, Warkoyo Warkoyo ${ }^{1}$, and Jumpen Onthong ${ }^{2}$}

${ }^{1}$ Department of Food Technology, Faculty of Agriculture and Animal Science, University of Muhammadiyah Malang, Jl. Raya Tlogomas No 246, Malang 65144 Indonesia

${ }^{2}$ Department of Earth Science, Faculty of Natural Resource, Prince of Songkla University, Hat Yai, Thailand

\begin{abstract}
Bread is main food in several country. Sweet bread is one popular type that has a lasting sweet taste and soft textured with or without stuffing. Baking is the most important process of bread production. The temperature and time required in the baking varies according to the type of bread, big dough, and baking pan in the oven used. This research aimed to identify the optimum level of baking temperature and duration to the chemical properties of sweet bread. Randomized Complete Block Design (RCBD) Factorial with 2 factors and 3 replications were applied for this research. The first factor was baking temperature consisted 4 level $\left(\mathrm{T} 1=180{ }^{\circ} \mathrm{C}, \mathrm{T} 2=\right.$ $190{ }^{\circ} \mathrm{C}, \mathrm{T} 3=200{ }^{\circ} \mathrm{C}, \mathrm{T} 4=210{ }^{\circ} \mathrm{C}$ ), and the second factor was baking duration which composed 4 level $(A 1=10$ minutes, $A 2=15$ minutes, $A 3=20$ minutes, $A 4=25$ minutes). The results showed that there wasn't interaction between baking temperature and duration to water content, fat, protein, and carbohydrate, but it was interaction to the ash content. The baking temperature and duration separatelly had significantly effect to the all parameter. The best result according to the SNI 01-3840-1995 was S4W4 $\left(185^{\circ} \mathrm{C}\right.$ : 14 minutes) with water content $(23.572 \%)$, fat $(10.906 \%)$, protein (1.105\%), carbohydrate (62.940\%), and ash content (1.736\%).
\end{abstract}

\section{Article History}

Received May 21, 2021

Accepted June 17, 2021

Keyword

Carbohydrate, Fat, Optimum Baking, Protein, Standardized bread

\section{Introduction}

Bread is main food, which has high calories, and commonly was made from main ingredient of wheat flour, yeast, water and salt that's baked (1). Bread has so many kind of shape, filling, texture and toping (2). There are 2 types of bread that divided based on sugar usage. The sweet bread applies $>20 \%$ of sugar, while plain bread use $<10 \%$ (3). Sweet bread making through several stages starting from the raw materials selection, weighing ingredients, stirring, while a resting, cutting and weighing, rounding, resting, forming, molding the dough in the pan, the final fermentation, shaping, baking, cooling process, and packaging (4). At the bread production, baking is important process that will affect sweet bread quality and quantity. Baking process is primarily related to the temperature and duration. The optimum baking temperature commonly $200{ }^{\circ} \mathrm{C}(5)$. Whereas, mostly it can be easily identified physically, but chemical properties need to be analyzed.

Physically the quality of sweet bread could be identified from the proofing, symmetrically shaping, color of bread crust, which is browning, texture, granules and pores (1). The granules should be soft and uniform, while the best texture commonly soft and elastic. The bread should be crumb, the quality of crumb can be identified from structure, 
color, aroma, and taste and shelf life. Mostly the bread so easily become stale after taken out from the oven. Therefore baking is primarily step from producing the bread.

Sweet bread main changes during heating or baking process is due to the component of sugar in food. Mostly the changing is non-enzymatic browning reaction, namely the maillard and caramelization reaction. Maillard is a reaction between carbohydrates, especially reducing sugars with primary amine group, the results of these reactions produce a brown material called melanoidin (6). Caramelization is a reaction that occurs due to heating of sugar at temperatures above its melting point, which will produce a change in color from dark to brown (7). Generally, the sugar used is sucrose (granulated sugar or cane sugar). Granulated sugar is non-reducing so it does not play a role in the Maillard reaction, only caramelization. Therefore this research is important to improve the chemical characteristics of sweet bread based on temperature or duration of baking, either interaction or separately of treatments. This research aimed to analyze the optimum level of baking temperature and duration to the chemical properties of sweet bread.

\section{Materials and Methods}

The materials used were consisted, high protein flour, emulplex, margarine, butter, bread improver, yeast, eggs, SP, sugar, salt, $\mathrm{H}_{2} \mathrm{SO}_{4} 98 \%, 50 \% \mathrm{NaOH}$, distilled water, boric acid, petroleum benzene, $\mathrm{Na}_{2} \mathrm{SO}_{4}: \mathrm{HgO}(20: 1)$ and $\mathrm{HCl} 0.02 \mathrm{~N}$. Randomized Complete Block Design Factorial was applied for this research. The first factor was baking temperature consisted 4 levels $\left(\mathrm{T} 1=180{ }^{\circ} \mathrm{C}, \mathrm{T} 2=190{ }^{\circ} \mathrm{C}, \mathrm{T} 3=200{ }^{\circ} \mathrm{C}, \mathrm{T} 4=210{ }^{\circ} \mathrm{C}\right)$, and the second factor was baking duration which also composed 4 levels ( $A 1=10$ minutes, $A 2=15$ minutes, $A 3=20$ minutes, $A 4=25$ minutes) all treatments were replied 3 times. The parameters that analyzed consisted water content, ash content, fat (Soxhlet method), protein (Kjedhal method), and carbohydrate (by difference). The procedure analysis was followed by AOAC (2016)(8). The sweet bread production process started by low velocity ( 5 minutes) ingredient mixing, fermentation ( $\left.\mathrm{T}=25-30{ }^{\circ} \mathrm{C} t=20\right)$, shaping, proofing, baking, and cooling process. The collected data were analyzed used Analysis of Variance (ANOVA), if the results showed significant were followed used Duncan Multiple Range Test (DMRT).

\section{Results and Discussion}

\subsection{Water Content}

Water content is an important parameter for dry products because of related to the food damage tendency. Bread is classified as a type of wet bread so that the water content is high enough to cause low durability. Water released product ability will enhance concomitantly temperature and duration which significantly affect to the decreasing water content (9). Based on analysis of variance (ANOVA), there wasn't interaction between baking temperature and duration to the water content (Table 1). Meanwhile, baking temperature and duration separately gave significant effect to the decreasing water content of sweet bread. The highest water content was S2W1 (175 ${ }^{\circ} \mathrm{C}: 8$ minutes) about $27.469 \%$, and the lowest was S4W4 $\left(185{ }^{\circ} \mathrm{C}: 14\right.$ minutes) about $23.572 \%$. This defined that the water content had a declining trend with increasing temperature and duration of oven process. It related to the ability of material to release water from its surface greater with the increasing temperature and longer duration of drying process (9) that resulted water content become 
lower. This was closely related to the amylose enhancement, which affected to the decreasing amylopectin and would increase water binding capacity $(10,11)$.

Moreover, during baking process, the water inside the dough was transferred through pores of dough to the surface. This resulted a transformation structure of dough become crumb and crust, as well as a water or moisture losses. The moisture loss during baking period was the highest compared to other processing steps.

\subsection{Fat Content}

The previous study defined that the small amounts of fat in bread doughs had a significant effect on the processing and on the final product quality. Such type of doughs were more extensible, and the machinability was markedly improved. After proofing, and shortening, the doughs were more stable and resistant. Based on analysis of variance (ANOVA), there wasn't interaction between baking temperature and duration to the fat, protein, and carbohydrate. The highest fat content was S1W1 (170 ${ }^{\circ} \mathrm{C}: 8$ minutes) about $13.827 \%$, and the lowest was S4W4 (185 ${ }^{\circ} \mathrm{C}: 14$ minutes) about $10.906 \%$. This result indicated inversely proportional. The baking temperature and duration affect to the decreasing fat content separately. The previous research found that fat value of bread was about 5.98\% (12) it means that sweet bread had higher fat content than plain bread (13). The optimum baking duration was required for desired structure, color, and water content of product. Mostly, the optimum time needed to dry product satisfactorily and determined the speed of baking. Fat strengthens the bread sidewalls and minimizes the keyholing possibility. Therefore, sweet breads had less crumbliness, and softer texture.

Table 1. Baking Temperature and Duration Effect to The Water Content, Fat Content, and Protein Content of Sweet Bread (mean \pm SD)

\begin{tabular}{lccc}
\hline $\begin{array}{c}\text { Treatment } \\
\text { (Temperature }: \text { Duration) }\end{array}$ & $\begin{array}{c}\text { Water } \\
\text { Content }\end{array}$ & Fat & Protein \\
\hline $\mathrm{S} 1 \mathrm{~W} 1\left(170^{\circ} \mathrm{C}: 8\right.$ minutes $)$ & $27.303 \pm 0.98$ & $13.827 \pm 0.19$ & $1.390 \pm 0.009$ \\
$\mathrm{~S} 1 \mathrm{~W} 2\left(170^{\circ} \mathrm{C}: 10\right.$ minutes $)$ & $26.480 \pm 0.47$ & $13.731 \pm 0.29$ & $1.384 \pm 0.02$ \\
$\mathrm{~S} 1 \mathrm{~W} 3\left(170^{\circ} \mathrm{C}: 12\right.$ minutes) & $26.157 \pm 0.41$ & $13.081 \pm 0.95$ & $1.349 \pm 0.03$ \\
$\mathrm{~S} 1 \mathrm{~W} 4\left(170^{\circ} \mathrm{C}: 14\right.$ minutes) & $25.891 \pm 0.32$ & $13.065 \pm 0.12$ & $1.331 \pm 0.05$ \\
$\mathrm{~S} 2 \mathrm{~W} 1\left(175^{\circ} \mathrm{C}: 8\right.$ minutes $)$ & $27.469 \pm 1.05$ & $13.023 \pm 0.07$ & $1.308 \pm 0.01$ \\
$\mathrm{~S} 2 \mathrm{~W} 2\left(175^{\circ} \mathrm{C}: 10\right.$ minutes $)$ & $25.822 \pm 0.21$ & $12.957 \pm 0.04$ & $1.261 \pm 0.05$ \\
$\mathrm{~S} 2 \mathrm{~W} 3\left(175^{\circ} \mathrm{C}: 12\right.$ minutes $)$ & $25.598 \pm 0.27$ & $12.969 \pm 0.17$ & $1.296 \pm 0.03$ \\
$\mathrm{~S} 2 \mathrm{~W} 4\left(175^{\circ} \mathrm{C}: 14\right.$ minutes $)$ & $25.315 \pm 0.33$ & $12.694 \pm 0.23$ & $1.273 \pm 0.04$ \\
$\mathrm{~S} 3 \mathrm{~W} 1\left(180^{\circ} \mathrm{C}: 8\right.$ minutes $)$ & $26.709 \pm 0.94$ & $12.338 \pm 0.29$ & $1.267 \pm 0.03$ \\
$\mathrm{~S} 3 \mathrm{~W} 2\left(180^{\circ} \mathrm{C}: 10\right.$ minutes $)$ & $25.023 \pm 0.29$ & $12.226 \pm 0.32$ & $1.267 \pm 0.04$ \\
$\mathrm{~S} 3 \mathrm{~W} 3\left(180^{\circ} \mathrm{C}: 12\right.$ minutes $)$ & $24.720 \pm 0.28$ & $11.398 \pm 1.02$ & $1.244 \pm 0.03$ \\
$\mathrm{~S} 3 \mathrm{~W} 4\left(180^{\circ} \mathrm{C}: 14\right.$ minutes $)$ & $24.517 \pm 0.36$ & $12.017 \pm 0.09$ & $1.226 \pm 0.02$ \\
$\mathrm{~S} 4 \mathrm{~W} 1\left(185^{\circ} \mathrm{C}: 8\right.$ minutes $)$ & $25.827 \pm 1.03$ & $11.875 \pm 0.14$ & $1.174 \pm 0.05$ \\
$\mathrm{~S} 4 \mathrm{~W} 2\left(185^{\circ} \mathrm{C}: 10\right.$ minutes $)$ & $23.920 \pm 0.60$ & $11.712 \pm 0.27$ & $1.156 \pm 0.04$ \\
$\mathrm{~S} 4 \mathrm{~W} 3\left(185^{\circ} \mathrm{C}: 12\right.$ minutes $)$ & $23.572 \pm 0.52$ & $11.516 \pm 0.16$ & $1.121 \pm 0.03$ \\
$\mathrm{~S} 4 \mathrm{~W} 4\left(185^{\circ} \mathrm{C}: 14\right.$ minutes $)$ & $23.313 \pm 0.54$ & $10.906 \pm 0.57$ & $1.105 \pm 0.06$ \\
\hline
\end{tabular}




\subsection{Protein Content}

The amount of protein and damaged starch in flour will influence the water amount that hold. Eventually, the water contributes about $45 \%$ of bread dough. Sugar in batter serve to decrease the gluten development strength due to its competition for water. It will inhibit the gliadin-glutenin-water complex, and gluten were weakened. Proteins mainly responsible for flour viscoelastic properties alike the gliadins (prolamins) and glutenins (glutelins). Gliadins are smaller monomeric which are responsible for dough extensibility. While, glutenins are large polymeric held together by disulphide bonds. These proteins give dough strength and elasticity, which affect to the final product quality.

Wheat flour (raw material) had high protein and it needed more water for producing gluten, which could save more gas, as the result, increasing water binding (13). The highest protein was S1W1 (170 ${ }^{\circ} \mathrm{C}: 8$ minutes) about $1.390 \%$ and decreased as increasing baking temperature. The starch granule without protein easily to be broken, and there was much water entry, and the starch proofing would be enhance (14).

\subsection{Carbohydrate Content}

Carbohydrates are important for gluten network development, the solubilizing of other material, and more tempting appearance to the final product, leavening agents aerate the batter and contribute to the product lightness. Heating process agitate the gelatinization, it was started by starch swelling, crystalline melting, dissolution, spreading, diffusion, and proofing (15). The highest carbohydrate value was S4W4 (185 ${ }^{\circ} \mathrm{C}: 14$ minutes) about $62.940 \%$, and it was directly proportional between the baking temperature and carbohydrate (Table 2). Based on analysis of variance, there was not interaction, the treatments gave significantly effect separately. During the mixing process, starch absorb a lot of water, and trap the gas. As the result it will produces little vesicle. It caused by sugar that's not only gave sweet taste, but also improve the color, and aroma by caramelization during baking process. Sugar had hygroscopic characteristics that were able to increase the sweet bread shelf time (16). The caramelization and maillard were important process for brown color establishment, and it would automatically affect the texture, taste, and aroma of sweet bread.

\subsection{Ash Content}

Ash content is closely related to the raw material, drying temperature and duration (17). The ash content of plain bread based on fish flour (8\%) and wheat flour (1.10\%), that were totally different and lower than SNI 01-3840-1995 (max 40\%)(18). Based on ANOVA, there was interaction between baking temperature and duration to the ash content. The highest ash content belong to the S4W4 (185 ${ }^{\circ} \mathrm{C}: 14$ minutes) $1.736 \%$ (Table 2). The increasing baking or drying temperature and duration would be automatically enhanced ash content of product $(19,20)$. 
Table 2. Baking Temperature and Duration Effect to The Carbohydrate and Ash Content of Sweet Bread (mean \pm SD)

\begin{tabular}{ccc}
\hline $\begin{array}{c}\text { Treatment } \\
\text { (Temperature }: \text { Duration) }\end{array}$ & Carbohydrate & Ash Content \\
\hline $\mathrm{S} 1 \mathrm{~W} 1\left(170^{\circ} \mathrm{C}: 8\right.$ minutes) & $56.374 \pm 0.83$ & $1.106 \pm 0.02$ \\
$\mathrm{~S} 1 \mathrm{~W} 2\left(170^{\circ} \mathrm{C}: 10\right.$ minutes $)$ & $56.934 \pm 0.84$ & $1.472 \pm 0.08$ \\
$\mathrm{~S} 1 \mathrm{~W} 3\left(170^{\circ} \mathrm{C}: 12\right.$ minutes) & $58.108 \pm 1.27$ & $1.306 \pm 0.05$ \\
$\mathrm{~S} 1 \mathrm{~W} 4\left(170^{\circ} \mathrm{C}: 14\right.$ minutes) & $57.975 \pm 0.28$ & $1.738 \pm 0.05$ \\
$\mathrm{~S} 2 \mathrm{~W} 1\left(175^{\circ} \mathrm{C}: 8\right.$ minutes $)$ & $56.891 \pm 1.01$ & $1.310 \pm 0.13$ \\
$\mathrm{~S} 2 \mathrm{~W} 2\left(175^{\circ} \mathrm{C}: 10\right.$ minutes $)$ & $58.644 \pm 0.10$ & $1.316 \pm 0.23$ \\
$\mathrm{~S} 2 \mathrm{~W} 3\left(175^{\circ} \mathrm{C}: 12\right.$ minutes $)$ & $58.645 \pm 0.49$ & $1.493 \pm 0.08$ \\
$\mathrm{~S} 2 \mathrm{~W} 4\left(175^{\circ} \mathrm{C}: 14\right.$ minutes $)$ & $59.102 \pm 0.21$ & $1.616 \pm 0.19$ \\
$\mathrm{~S} 3 \mathrm{~W} 1\left(180^{\circ} \mathrm{C}: 8\right.$ minutes $)$ & $58.370 \pm 1.12$ & $1.316 \pm 0.17$ \\
$\mathrm{~S} 3 \mathrm{~W} 2\left(180^{\circ} \mathrm{C}: 10\right.$ minutes $)$ & $60.169 \pm 0.29$ & $1.316 \pm 0.15$ \\
$\mathrm{~S} 3 \mathrm{~W} 3\left(180^{\circ} \mathrm{C}: 12\right.$ minutes $)$ & $61.161 \pm 1.12$ & $1.478 \pm 0.15$ \\
$\mathrm{~S} 3 \mathrm{~W} 4\left(180^{\circ} \mathrm{C}: 14\right.$ minutes $)$ & $60.641 \pm 0.41$ & $1.598 \pm 0.04$ \\
$\mathrm{~S} 4 \mathrm{~W} 1\left(185^{\circ} \mathrm{C}: 8\right.$ minutes $)$ & $59.953 \pm 1.15$ & $1.171 \pm 0.03$ \\
$\mathrm{~S} 4 \mathrm{~W} 2\left(185^{\circ} \mathrm{C}: 10\right.$ minutes $)$ & $61.675 \pm 0.58$ & $1.537 \pm 0.01$ \\
$\mathrm{~S} 4 \mathrm{~W} 3\left(185^{\circ} \mathrm{C}: 12\right.$ minutes $)$ & $62.453 \pm 0.63$ & $1.339 \pm 0.03$ \\
$\mathrm{~S} 4 \mathrm{~W} 4\left(185^{\circ} \mathrm{C}: 14\right.$ minutes $)$ & $62.940 \pm 0.86$ & $1.736 \pm 0.05$ \\
\hline
\end{tabular}

\section{Conclusions}

There was interaction between baking temperature and duration to the ash content. Meanwhile baking temperature and duration separately affect to the water content, fat, protein, carbohydrate, and ash content. The best result according to the SNI 01-3840-1995 was S4W4 (185 ${ }^{\circ} \mathrm{C}: 14$ minutes) with water content $(23.572 \%)$, fat (10.906\%), protein $(1.105 \%)$, carbohydrate $(62.940 \%)$, and ash content $(1.736 \%)$.

\section{Acknowledgements}

The authors are grateful to Faculty of Agriculture and Animal Science of the University of Muhammadiyah Malang (UMM) funding number E.2.b/880.a/FPPUMM/V/2018. We also thank the assistants of the Food Technology Laboratory, Faculty of Agriculture and Animal Science, UMM for their support at all levels of experimentations.

\section{Author Contributions}

Devi Dwi Siskawardani and Warkoyo Warkoyo conceived and designed the experiments; Devi Dwi Siskawardani performed the experiments; Devi Dwi Siskawardani and Warkoyo Warkoyo analyzed the data; Warkoyo Warkoyo contributed reagents/materials/analysis tools; Devi Dwi Siskawardani and Warkoyo Warkoyo wrote the paper. 


\section{References}

1. Anggraeni MC, Nurwantoro N, Abduh SBM. Sifat Fisikokimia Roti yang Dibuat Dengan Bahan Dasar Tepung Terigu yang Ditambah Berbagai Jenis Gula. J Apl Teknol Pangan. 2016;6(1).

2. Feiner G. Meat Products Handbook, Practical Science and Technology. Cambridge: Woodhead Publishing Limited; 2006.

3. Koswara S. Teknologi Modifikasi Pati. Ebook. 2009.

4. Purlis E, Salvadori VO. Bread browning kinetics during baking. J Food Eng. 2007;80(4):1107-15.

5. Kurniawan F, Hartini S, Hastuti D. Pengaruh Pemanasan Terhadap Kadar Pati Dan Gula Reduksi pada Tepung Biji Nangka (Artocarpus Heterophyllus Lamk). In: Prosiding Seminar Nasional Sains dan Pendidikan Sains X BI/KI/MA. 2015. p. 1-10.

6. Winarno. Kimia Pangan dan Gizi. Jakarta, Indonesia: PT. Gramedia Pustaka Utama; 2008.

7. Flander L, Salmenkallio-Marttila M, Suortti T, Autio K. Optimization of ingredients and baking process for improved wholemeal oat bread quality. LWT-Food Sci Technol. 2007;40(5):860-70.

8. Horwitz W, Chichilo P, Reynolds H. Official methods of analysis of the Association of Official Analytical Chemists. Off methods Anal Assoc Off Anal Chem. 1970;

9. Fitriani S. Pengaruh Suhu dan Lama Pengeringan Terhadap Beberapa Mutu Manisan Belimbing Wuluh (Averrhoa bilimbi L.) Kering. J Sagu. 2008;7(01).

10. Wootton $\mathrm{M}$, Bamunuarachchi $\mathrm{A}$. Water binding capacity of commercial produced native and modified starches. Starch-Stärke. 1978;30(9):306-9.

11. Cornejo-Ramírez YI, Martínez-Cruz O, Del Toro-Sánchez CL, Wong-Corral FJ, BorboaFlores J, Cinco-Moroyoqui FJ. The structural characteristics of starches and their functional properties. CyTA-Journal Food. 2018;16(1):1003-17.

12. PS F, Suhaidi I, Z L. Evaluasi Karakteristik Fisik, Kimia, dan Sensori dari Tepung Komposit Terigu, Ubi Kayu, Kedelai, dan Pati Kentang dengan Penambahan Xantham Gum [Physical, Chemical, and Sensory Characteristics Evaluation of Bread from Composite Flour of Wheat, Cassava, So. J Rekayasa Pangan dan Pertan. 2014;2(1):7684.

13. De La Hera E, Rosell CM, Gomez M. Effect of water content and flour particle size on gluten-free bread quality and digestibility. Food Chem. 2014;151:526-31.

14. Jekle M, Mühlberger K, Becker T. Starch-gluten interactions during gelatinization and its functionality in dough like model systems. Food Hydrocoll. 2016;54:196-201.

15. Silva AC, Silva EMS, Peres AEC, Sousa DN. Temperature influence in cornstarch gelatinization for froth flotation. REM-International Eng J. 2017;70:231-5.

16. Ding S, Yang J. The effects of sugar alcohols on rheological properties, functionalities, and texture in baked products-A review. Trends Food Sci Technol. 2021;

17. Matin A, Krička T, Jurišić V, Voća N, Žunić J, Grubor M. Effects of different air drying temperature on sunflower seeds oil and ash content. J Process Energy Agric. 2017;21(1):5-8.

18. Dwi RWSDH, Rosida A. Aspek mutu produk roti tawar untuk diabetesi berbahan baku tepung porang dan tepung suweg. AGROKNOW. 2014;2(01).

19. Liu K. Effects of sample size, dry ashing temperature and duration on determination of ash content in algae and other biomass. Algal Res. 2019;40:101486. 
20. Bikila AM, Tola Y, Esho TB, Forsido SF. Effect of predrying treatment and drying temperature on proximate composition, mineral contents, and thermophysical properties of anchote (Coccinia abyssinica (Lam.) Cogn.) flour. Food Sci Nutr. 2020;8(10):5532-44. 